\title{
A Comparative Study of Private Security Regulations of Mongolia, Belgium and the United Kingdom
}

\begin{tabular}{l}
\hline $\begin{array}{l}\text { Galbat Lkhagvamaa' (iD) } \\
\text { Julak Lee }{ }^{2}\end{array}$ \\
$\begin{array}{l}{ }^{1} \text { Professor, Law Enforcement University, Mongolia } \\
{ }^{2} \text { Professor, Kyonggi University, Republic of Korea }\end{array}$ \\
\hline
\end{tabular}

\begin{abstract}
Regulation of the private security industry in Mongolia is relatively recent with the first specific legislation dating back to 2000. In 2000, the State Great Hural(Parliament of Mongolia) passed the Law on Contracted Private Security Service and has been revised twice, by which 'modern' private security was legally born. The aim of this study is to compare and evaluate the regulation of private security in the Mongolia, Belgium and the United Kingdom. In particular, this study illustrates the differences which exist in the level of regulation governing the operation of the industry in these countries in four areas such as areas covered private security companies, entrance requirement for companies, restriction on the background of owner/management, restriction on the background of employee, training/education. The comparative study of the three countries shows an imperative need to make further amendments to the Law on Contracted Private Security Service. According to the findings, this study proposes the direction for constructive amendments to strengthen the Law on Contracted Private Security Service.
\end{abstract}

Keywords: Private security, Security regulations, Mongolia, Belgium, United Kingdom.

\section{Contents}

1. Introduction

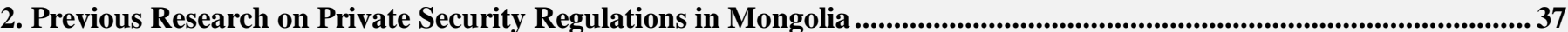

3. Comparison of Private Security Regulations of Mongolia, Belgium and the United Kingdom............................................ 37

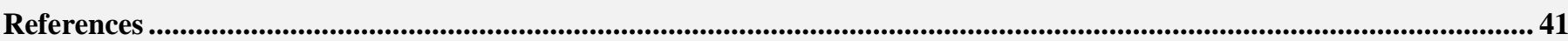

Citation | Galbat Lkhagvamaa; Julak Lee (2017). A Comparative Study of Private Security Regulations of Mongolia, Belgium and the United Kingdom. Asian Journal of Social Sciences and Management Studies, 4(1): 36-41.
DOI:
10.20448/journal.500/2017.4.1/500.1.36.41 Crossref
ISSN(E) :
$\operatorname{ISSN}(\mathbf{P}):-2518-0096$
Licensed: $\quad$ This work is licensed under a Creative Commons Attribution 3.0 License (cc)
Contribution/Acknowledgement: All authors contributed to the conception and design of the study.
Funding: $\quad$ This study received no specific financial support.
Competing Interests: The authors declare that they have no conflict of interests.
Transparency: $\quad$ The authors confirm that the manuscript is an honest, accurate, and transparent account of the study was reported; that no vital features of the study have been omitted; and that any discrepancies from the study as planned have been explained.
History:
Ethical: Received: 24 November 2016/ Revised: 20 December 2016/ Accepted: 30 December 2016/ Published: 13 January 2017 This study follows all ethical practices during writing.
Publisher: Asian Online Journal Publishing Group 


\section{Introduction}

The aim of this study is to compare and evaluate the regulation of private security in the Mongolia, Belgium and the United Kingdom. While no research has been found with regard to the regulation of private security in Mongolia. For Mongolia, it is crucial to study experiences of foreign countries, especially those where private security service has been developed well, in order to improve legal regulations of the security service. Thus, the purposes of this comparative study are to study how the legal environment of the private security service has been formed and compare relevant legislation for the further analysis.

This study employs the method of comparative analysis based upon previous and present legislations in Mongoli a related to private security and agency records and statistics. This study also investigates other cases of legal regulati on of private security such as case of some European countries. There are some problems in comparing different regu latory systems and varied private security industries. A fundamental problem is the lack of information available in di fferent countries, furthermore, is not comparable, and often differing methodologies are used, which make compariso ns difficult (Lee, 2008).

Methods of data collection depend upon examining written legal resources in legal development of Mongolian laws and enactments on public and private security service adopted in Mongolia since 1990s. However, it is necessary to underline that the data on which this study is based varies in terms of its quality. This study represents, a formal picture of the state of legislation in three countries; it does not contribute to clarifying the understanding of foreign private security companies in practice. Therefore, although it provides an idea of numerous regulations that are in place in each country, it does not tell us whether the rules are strictly implemented and enforced in practice.

\section{Previous Research on Private Security Regulations in Mongolia}

Although the Law on Contracted Private Security Service has been implemented since 2001, there still is no fundamental research in this field. Few authors, namely, Davaadorj and Batjav (2009) "Grounds of the contracted security service activity"; (Chuluunbat, 2014) "Protection of the object"; (Khurelbaatar, 2014) "Some issues of the protection of the object"; (Kaplonski, 2008) "Theory and methods of the protection" and Odmandakh (2009) "Contracted private security service"; (Bayanmunkh, 2013). "Compilation of legal documents respective contract private security company's activity". But in the study of the private security service, these works concern more the issues on protection of objects and theory of security service. The legal regulations of the activities of the contracted private security service have been enlighten in brief in works of Davaadorj and Batjav (2009) "Grounds of the contracted security service activity", Odmandakh (2009) "Contracted private security service".

It is important to note that the main resources of this research work are laws and enactments on public and privat e security service adopted in Mongolia since 1990s. There are definitely different from those that were in application before 1990s, and it should be noted that the new regulations have been determining the legal grounds of the private security service in the circumstances of the new social relations. There is still lack of fundamental comprehensive res earches of the respective legal instruments scientifically in Mongolia.

\section{Comparison of Private Security Regulations of Mongolia, Belgium and the United Kingdom}

Regulation of the private security industry in Mongolia is relatively new, with the first specific legislation dating back to 2000. The Parliament of Mongolia passed the Law on Contracted Private Security Service in 2000 and has been revised twice (Purev, 2011). The Law on Contracted Private Security Service includes provisions for registering, requirements for private security company, limitation of private security activities, contract of security service, training content and curricula of private security staff, obligations of security service companies, its personnel as well as clients, qualifications of personnel, oversight of security service and penal clause.

The establishment of the first private security undertakings in Belgium dates back to 1905 (Weber, 2002). The pri vate security is governed by the law on Private and Special Security of 1990, (last modified on 10 June 2001) and Ro yal Decree of 31/12/ 1999 on training and law on the Use of Arms of 30 January 1991 and the law of 19.06.1991 on Private Investigators.

The United Kingdom for long time exceptional for having the largest private security market with little or no regulation. This has recently been changed with Private Security Industry Act (May 2001) which is currently being implemented. This act has been amended twice in 2006. Security Industry Authority (SIA) is competent national authority in charge of drafting and amending legislation regulating the private security industry (Private Security Services in Europe, 2011). Despite these new regulations, controls and coverage of legislation are set to remain rather minimal, although the conditions and controls of licensing still needs to be implemented by the SIA. Besides the legal framework, a wide range of standards and inspectorates have supervised security industry in the UK. The BSIA is the most prominent of the trade associations which have carried out self-regulation in this sector. The lack of legal regulations is now changing with the implementation of new legislation (Weber, 2002).

The following section illustrates the differences which exists in the level of regulation governing the operation of the industry in the three countries in areas such as areas covered private security companies, entrance requirement for companies (licensing, financial viability), restriction on the background of owner/management (criminal background, cumulation, age limits, training), and restriction on the background of employee, training/education (basic training, examination, continuous training, accreditation of trainers providers).

\subsection{Area Covered by Private Security Companies}

Private security companies offer a great variety of services in these countries, which can be divided into the following 7 categories. First, private security companies offer the protection of sites and buildings, including airport, harbors, nuclear power plants. This category also includes setting up and maintaining alarm response services and 
video surveillance (CCTV) in all countries where studied. Second, private security companies offer protection services for valuables and cash in transit in all countries where studied. Third, private security companies offer guarding and control of persons and access in public place in all countries where studied. Fourth, private security companies offer guarding of goods and persons all countries where studied. Fifth, private security companies offer private investigators (in Belgium and United Kingdom). Sixth, private security companies offer close protection services, such as bodyguards in all countries where studied. Seventh, private security companies offer security consultancy in Belgium and Mongolia.

Table-1. Key legislation governing the industry in each state

\begin{tabular}{|c|c|c|c|}
\hline Country & Legislation & Areas covered by the legislation & General characteristics of the sector \\
\hline $\begin{array}{l}\text { United } \\
\text { Kingdom }\end{array}$ & $\begin{array}{l}\text { Private Security } \\
\text { Industry act }\end{array}$ & $\begin{array}{l}\text { General guarding Airport security } \\
\text { Maritime security Cash-In-transit } \\
\text { Monitoring and remote surveillance Door } \\
\text { supervisors Close protection/ body } \\
\text { guarding }\end{array}$ & $\begin{array}{l}\text { The UK was for long time exceptional for having } \\
\text { the largest private security market with little or no } \\
\text { regulation. This has been changed with the Private } \\
\text { Security Industry Act (2001). } \\
\text { The law does not allow armed private security } \\
\text { service. } \\
\text { Beside the legal framework, wide range of } \\
\text { standards and inspectorates have supervised the } \\
\text { UK security industry. }\end{array}$ \\
\hline Belgium & $\begin{array}{l}\text { law on Private } \\
\text { and Special } \\
\text { Security }\end{array}$ & $\begin{array}{l}\text { General guarding Airport security } \\
\text { Maritime security Cash in transit (CIT) } \\
\text { Monitoring and remote surveillance } \\
\text { Other segments such as body guarding, } \\
\text { mobile guarding, control of persons, } \\
\text { accompanying of secured special } \\
\text { transport. } \\
\text { Consultancy }\end{array}$ & $\begin{array}{l}\text { Legislation in Belgium is rather strict and } \\
\text { emphasizes the protection of citizens from any } \\
\text { abuse of power by private security providers. }\end{array}$ \\
\hline Mongolia & $\begin{array}{l}\text { Law on } \\
\text { Contracted } \\
\text { Private Security } \\
\text { Service Law on } \\
\text { Personal } \\
\text { Protection }\end{array}$ & $\begin{array}{l}\text { Guarding of transit of valuables, cash and } \\
\text { transit } \\
\text { Airport security Guarding of persons } \\
\text { Guarding and control persons and access } \\
\text { in public place Security consultancy } \\
\text { Installation and maintenance of alarm } \\
\text { systems } \\
\text { Body guarding Guarding of buildings }\end{array}$ & $\begin{array}{l}\text { The private security industry in Mongolia is largely } \\
\text { governed by Law on contracted private security } \\
\text { service and Law on Personal protection. } \\
\text { Legislations in Mongolia basically focuses on } \\
\text { contract security. }\end{array}$ \\
\hline
\end{tabular}

\subsection{Entrance Requirements}

The regulation of entrance requirements for companies active in the industry are generally designed to provide for: Checks on financial viability and Checks on reputable of nature of the management team of company. Difference in requirements across the countries therefore pose potential uncertainties when companies seek to provide services across national borders.

\subsubsection{Licensing}

Across the countries, provisions vary as to the entrance requirements to be fulfilled by companies setting up to provide private security services. All countries operate system of licensing for private security companies. In the UK only, companies may be approved under a voluntary inspection arrangement. Licensing is limited to individuals. License valid ranges from 1 to 5 years. However, there is significant variation in the nature and level of information required for license to be granted, level of rigor of implementation and the level at which licenses are approved and reviewed.

\subsubsection{Financial Viability}

While doing this research we tried to analyze the minimum financial viability checks at international level but it was impossible due to the lack of relevant data. The granting of license to private security undertakings need to be closely linked with checks on background of owners and managerial staff of private security companies to prevent the establishment of companies by individuals with unsuitable background of private security. In Belgium and the UK financial viability checks are required. The most restrictive legislation on entrance requirements is in place in Belgium, where license are required and time limited.

Table-2. Entrance requirements for companies

\begin{tabular}{l|l|l|l}
\hline Country & License required? & Awarding authorities & Other entrance requirements \\
\hline $\begin{array}{l}\text { United } \\
\text { Kingdom }\end{array}$ & $\begin{array}{l}\text { Companies may be approved under } \\
\text { the voluntary inspection } \\
\text { arrangement. Licensing is limited to } \\
\text { individuals and is valid for 3 years. }\end{array}$ & $\begin{array}{l}\text { The Security Industry } \\
\text { Authority }\end{array}$ & $\begin{array}{l}\text { The Private Security Industry Act introduces a } \\
\text { voluntary scheme for providers of security services to } \\
\text { apply for approved status. }\end{array}$ \\
\hline Belgium & $\begin{array}{l}\text { Yes, License is mandatory. } \\
\text { license is valid for 5 years }\end{array}$ & $\begin{array}{l}\text { Ministry of the Interior in } \\
\text { consultation with Ministry } \\
\text { of Justice. }\end{array}$ & $\begin{array}{l}\text { Insurance requirements. At least one manager must have } \\
\text { followed compulsory training for managers and at least one } \\
\text { person must have followed compulsory training for the } \\
\text { activity for which license is requested. } \\
\text { Necessary infrastructure and material required for the } \\
\text { activity for which the license is requested. }\end{array}$ \\
\hline Mongolia & $\begin{array}{l}\text { Law on Contracted Private Security } \\
\text { Service requires a certificate } \\
\text { Certificate is valid for 1 year. }\end{array}$ & $\begin{array}{l}\text { Metropolitan Police and } \\
\text { local Police station. }\end{array}$ & $\begin{array}{l}\text { Necessary material (page of 128 chapter 4.2) required } \\
\text { for the activity for which the certificate is required. }\end{array}$ \\
\hline Source: Gantumurand Lkhagvamaa (2009)
\end{tabular}




\subsection{Restriction on the Background of Owner/Management Team}

Legislation and regulations governing the background of owners and managers of private security companies currently relate to the following factors: Criminal background, Minimum age requirements, Cumulation with other activities, Qualifications and Financial viability.

All countries currently have some form of regulation governing the restrictions placed on the background of owners and management team of private security undertakings, except Mongolia. However, number of differences arise in relation to level of restrictions imposed and the way in which compliance is verified.

\subsubsection{Criminal Background}

The most comprehensive definition of exclusion criteria can be found in Belgium. Important differences exists with regard to the level at which background checks a carried out (by national or local authority, by representative of the sector or by companies themselves). Which could have an impact on the rigor of such background checks.

\subsubsection{Cumulation}

A significant of number of countries see the management of private security undertakings as being incompatible with a number of other activities and therefore forbid the cumulation of such tasks with those of the ownership and management of a private security company. Examples include the activities of private investigation and role of a civil servant. Cumulation with activities in forbidden in Belgium.

\subsubsection{Age Limits}

Age limits are imposed by all countries, the limit is generally set at 18 , with the exception of Belgium which set age limits of 21 .

\subsubsection{Training}

Belgium needs not only operational staff but also managerial staffs to receive certain hours of training. However, training is not required for management staffs in United Kingdom and Mongolia. The highest level of regulation in relation to on background of owners and staff can be found in Belgium, where precise exclusion criteria and cumulation restrictions apply.

Table-3. Restriction of owner and management staff

\begin{tabular}{|c|c|c|c|c|}
\hline Country & Criminal record & Minimum age & $\begin{array}{l}\text { Restrictions on cumulation } \\
\text { with other activities }\end{array}$ & $\begin{array}{l}\text { Other } \\
\text { requirements }\end{array}$ \\
\hline $\begin{array}{l}\text { United } \\
\text { Kingdom }\end{array}$ & $\begin{array}{l}\text { Legislation requires a criminal records } \\
\text { check. License required which is valid } \\
\text { for } 3 \text { years and renewable. Employees } \\
\text { should be fit and proper persons, skilled } \\
\text { and fulfilling the demands for insurance, } \\
\text { training and registration. }\end{array}$ & 18 & No provisions & $\begin{array}{l}\text { Financial } \\
\text { viability check }\end{array}$ \\
\hline Belgium & $\begin{array}{l}\text { Precise exclusion criteria are set based } \\
\text { on criminal record. Investigations } \\
\text { carried out by official nominated by } \\
\text { Ministry of Justice. Owners and } \\
\text { managers should fulfill the demands of } \\
\text { the morality check carried out by federal } \\
\text { police. }\end{array}$ & 21 & $\begin{array}{l}\text { Cumulation forbidden with } \\
\text { private detective work and } \\
\text { production or dealing of } \\
\text { arms, or any other } \\
\text { occupation likely endanger } \\
\text { public safety. Must not have } \\
\text { been member of police and } \\
\text { secret service in last } 5 \text { years. }\end{array}$ & $\begin{array}{l}\text { Financial } \\
\text { viability check } \\
\text { Health status } \\
\text { Training } \\
\text { required }\end{array}$ \\
\hline Mongolia & No relevant criminal record & $\begin{array}{l}\text { No specific } \\
\text { provisions }\end{array}$ & & \\
\hline
\end{tabular}

Source: Gantumur and Lkhagvamaa (2009)

\subsection{Restriction on the Background of Employee}

The regulation and implementation of strict background checks for the staff of private security companies is therefore one of the main concerns of legislation in this area. The legislation and regulation governing the background of employees are similar to those for owners and managers of private security companies and currently primarily relates to the following factors: Criminal background, Minimum age requirement, Qualification and Simulation with other activities

\subsubsection{Criminal Background}

All countries where studied require a criminal background check. In most cases this is carried by the police but in some cases for example: in United Kingdom all operational staff will have to undergone a criminal background check carried out by either Security Industry Authority or the local Authority in order to obtain a license prior to being employed.

\subsubsection{Age Limits}

Age limits are imposed, by all countries, the limit is generally set at 18 at the legal age of maturity.

\subsubsection{Training}

All countries currently require security guards to undergo a course of basic training. 
Table-4. Restriction on background of employees

\begin{tabular}{|c|c|c|c|c|}
\hline Country & Criminal record & $\begin{array}{l}\text { Minimum } \\
\text { age }\end{array}$ & $\begin{array}{l}\text { Restrictions on cumulation with } \\
\text { other activities }\end{array}$ & $\begin{array}{l}\text { Other } \\
\text { requirements }\end{array}$ \\
\hline $\begin{array}{l}\text { United } \\
\text { Kingdom }\end{array}$ & $\begin{array}{l}\text { Completing a Criminal Record } \\
\text { Bureau criminal record check. } \\
\text { License required which will be } \\
\text { valid for } 3 \text { years and renewable. }\end{array}$ & 18 & No specific provisions & $\begin{array}{l}\text { A medical } \\
\text { examination } \\
\text { A psychological } \\
\text { examination }\end{array}$ \\
\hline Belgium & $\begin{array}{l}\text { License to be obtained from the } \\
\text { Ministry of the Interior. Legislation } \\
\text { requires a criminal background } \\
\text { check. Individuals must not have } \\
\text { been sentenced to more than } 6 \\
\text { months in prison or any criminal } \\
\text { offence or lesser term for a } \\
\text { relevant offence. Ministry of } \\
\text { Justice carry out investigations by } \\
\text { official nominated. }\end{array}$ & 18 & $\begin{array}{l}\text { Cumulation forbidden with private } \\
\text { detectivework and production or } \\
\text { dealing of arms, or any other } \\
\text { occupation that might present danger } \\
\text { to the state. Must not have been } \\
\text { member of police and secret service } \\
\text { in last } 5 \text { years. Private investigators } \\
\text { are forbidden no investigate } \\
\text { political, philosophical religious or } \\
\text { union beliefs. }\end{array}$ & $\begin{array}{l}\text { Positive } \\
\text { medical } \\
\text { examination } \\
\text { Positive } \\
\text { psychological } \\
\text { examination } \\
\text { Successfully } \\
\text { completed } \\
\text { compulsory } \\
\text { training }\end{array}$ \\
\hline Mongolia & $\begin{array}{l}\text { Criminal background check is } \\
\text { required }\end{array}$ & 20 & No specific provisions & $\begin{array}{l}\text { Health check, } \\
\text { Training } \\
\text { required. }\end{array}$ \\
\hline
\end{tabular}

\subsection{Training/Education}

It is in the area of training and education that provisions vary most significantly between the countries which we studied. This is an area which is inextricably linked with the image and developing professionalism of the sector, but also significant problems relating to freedom of movement through the lack of portability of qualifications. Differences between countries relate to the following aspects: Is training obligatory and voluntary?, Are examinations required?, Are provisions made for obligatory continuous training?, and How is the quality of trainers and training providers regulated?

\subsubsection{Basic Training}

Belgium currently provides for some form of obligatory training for private security guards. Training in Mongolia and the United Kingdom is obligatory for operational staff and the management staff is voluntary. The SIA with prescribe the conditions regarding training the licensee is to undergo or maintain. In order to improve comparability and to increase professionalism in the sector, it seems appropriate to enhance a national level requirement for obligatory basic (theoretical and practical) training by comparing these countries.

Table-5. Education/ Training

\begin{tabular}{|c|c|c|c|c|}
\hline Country & $\begin{array}{l}\text { Obligatory/ voluntary initial } \\
\text { training and duration }\end{array}$ & Examinations & Continuous training & $\begin{array}{l}\text { Training } \\
\text { providers/control over } \\
\text { training providers }\end{array}$ \\
\hline $\begin{array}{l}\text { United } \\
\text { Kingdom }\end{array}$ & $\begin{array}{l}\text { Training is obligatory for } \\
\text { operational staff but training is } \\
\text { not obligatory for management } \\
\text { staff. The SIA with prescribe } \\
\text { the conditions regarding } \\
\text { training the licensee is to } \\
\text { undergo or maintain. }\end{array}$ & & No regulated & $\begin{array}{l}\text { The trainings are provided } \\
\text { by the company, colleges } \\
\text { and other training } \\
\text { providers. }\end{array}$ \\
\hline Belgium & $\begin{array}{l}\text { Obligatory. Length of training } \\
\text { varies depending on sector } \\
\text { activity. } \\
\text { Managerial staff } 52-100 \text { hours; } \\
\text { operational staff } 127 \text { hours. }\end{array}$ & $\begin{array}{l}\text { Yes, certificate } \\
\text { awarded for } 5 \\
\text { years. }\end{array}$ & $\begin{array}{l}\text { Follow-up or refresher } \\
\text { training exits. } \\
\text { The follow-up or refresher } \\
\text { training is mandatory by } \\
\text { law and organized every } 5 \\
\text { years. } \\
\text { First aid training is and } \\
\text { refresher course are } \\
\text { mandatory by labor law and } \\
\text { organized each year. }\end{array}$ & $\begin{array}{l}\text { The training is provided by } \\
\text { certified training institutes, } \\
\text { which are licensed by the } \\
\text { Ministry of the Interior. }\end{array}$ \\
\hline Mongolia & $\begin{array}{l}\text { Training is obligatory for } \\
\text { operational staff but training is } \\
\text { not obligatory for management } \\
\text { staff. } \\
\text { Training is regulated by } \\
\text { Ministry of Justice. } 42 \text { hours } \\
\text { of theoretical instruction and } \\
38 \text { hours of practical } \\
\text { experience. }\end{array}$ & $\begin{array}{l}\text { Examination } \\
\text { and } \\
\text { certification }\end{array}$ & Not obligatory & $\begin{array}{l}\text { Training takes place in } \\
\text { Law enforcement } \\
\text { university and centers } \\
\text { approved for this purpose } \\
\text { by the Mongolian National } \\
\text { Police. } \\
\text { Internal and external } \\
\text { controls are carried out for } \\
\text { initial and training. }\end{array}$ \\
\hline
\end{tabular}




\subsubsection{Examination}

Countries with obligatory training generally require trainee to pass an examination either after each module of study or at the end of the course. In some cases, the certification gained is time limited thus providing for the regular updating of skills. This is the case in Belgium.

\subsubsection{Continuous Training}

Currently, Belgium makes explicit provision for obligatory continuous training 8 hours every 5 years for operatio nal staff. In all other countries continuous training is voluntary. In the light of rapid operational and technological inn ovations in the sector, consideration should be given to national level regulation relating to the regular updating of sk ills for operational and managerial staff in the sector.

\subsubsection{Accreditation of Trainers and Training Providers}

Many countries make provision for state or industry accreditation of trainer and training providers to allow for a level of financial and quality control. Curricula are often set in co-ordination with representative organizations of the industry thus providing for regular updating for training programs to reflect development in the sector and needs of employers. In majority of cases, employers fund basic training, sometimes with the assistance of state grants. In some cases, guards are responsible for funding their own training costs.

\section{Conclusion}

The question of enhancing the laws and regulations should be a sustainable process, not merely limited to enact new laws and regulations or to introduce amendments therein, but a focus should be made on how to enforce the existing laws and regulations in keeping with life realities and on how to ensure the correlation of laws with changing life realities and challenges and on the ways of how to secure the interdependence and the interrelation between the provisions of all laws and regulations concerned (Gantumur and Lkhagvamaa, 2009). In other words, the precondition for the law enforcement process to become a reality can be ensured in the case if any law is enacted based on the life realities and life imperatives and if its practical implementation is also ensured in strict correlation with the other laws and regulations concerned.

On the basis of the comparative study made on the legal regulations governing the private security service indust ry as discussed in the previous section, we wish to make the following conclusion. Despite the fact that the legal regu lations governing the private security service industry in Mongolia are in conformity with the established internation al standards and practices, still there is an imperative need:

-to revise, where necessary, and correctly define the names of laws and the legal terms and references therein;

-to improve the procedures and operations for the registration of the legal entities applying for running the private security service activities;

-to change or extend the term of validity of licenses for the private security service entities;

-to toughen up the requirements both with regard to chief-executive and to security service officers and to make them equally accountable for their actions and responsibilities;

-to expand the framework of the activities and the power of the union of the private security service officers.

\section{References}

Bayanmunkh, B., 2013. Compilation of legal documents respective contract private security company's activity. Kitab Publishing Co.

Chuluunbat, B., 2014. Protection of object. Ulaanbaatar, Mongolia: Soyombo Press.

Davaadorj, D. and B. Batjav, 2009. Grounds of the contracted private security service activity. Ulaanbaatar, Mongolia: Bit Press Publishing Company.

Gantumur, G. and G. Lkhagvamaa, 2009. Pardon and its legal regulation. Munkhiin Useg Press.

Kaplonski, C., 2008. Prelude to violence: Show trials and state power in 1930s Mongolia. American Ethnologist, 35(2): 321-337. View at Google Scholar $\mid$ View at Publisher

Khurelbaatar, T., 2014. Some issues of the protection of the object. Ulaanbaatar, Mongolia: Munkhiin Useg Press.

Lee, C.M., 2008. A comparative study on regulation of private security in the United States and South Korea. Journal of Applied Security Research, 3(2): 157-170. View at Google Scholar | View at Publisher

Odmandakh, B., 2009. Contract private security service. Ulaanbaatar, Mongolia: Soyombo Press.

Private Security Services in Europe, 2011. CoEES fact \& figures. Confederation of European Security: 1-255.

Purev, B., 2011. History of the development of the legal regulations for police organizations: The foundation of the legal basis for police organization. Compilation of Report of Conference, The National Police Agency printing Office. pp: 35-37.

Weber, T., 2002. A comparative overview of legislation governing the private security industry in the European Union. Birmingham: ECOTEC Research and Consulting. 